\title{
Culture and the Environment on the Floodplain of the River Cauca in southwestern Colombia: reconstructing the Evidence from the Late Pleistocene to the Late Holocene.
}

Marianne Cardale de Schrimpff. Pro Calima Foundation for Archaeological Research, Calle 92, No. 11A - 56, Apartamento 701, Bogotá, Colombia marianne@procalima.org

Juan Carlos Berrio. Department of Geography, University of Leicester, U.K. jcb34@le.ac.uk

Ana Maria Groot. Departamento de Antropología, Universidad Nacional, Bogotá amgrootd@unal.edu.co Pedro Botero Independent scholar, Carrera 52A, No. 57B-33, Apartamento 421, Bogotá. guiaspedro@gmail.com Neil Duncan Department of Anthropology, University of Central Florida, U.S.A.

Neil.Duncan@ucf.edu

\begin{abstract}
This paper summarizes the results of on-going archaeological and palaeoecological research on the floodplain of the river Cauca and adjacent piedmont, with the aim of reconstructing an outline history of the human occupation of the region and its interaction with the environment, beginning in the Late Pleistocene. The difficulties of locating occupation sites in this landscape cannot be overestimated. Although valuable for its preservation of palaeosols, the accumulation of sediment deposited by the river Cauca and its tributaries during periods of flooding can be extremely rapid and the earlier archaeological sites (1000 B.C. to 500 A.D.) are generally buried beneath several metres of alluvium. Under these circumstances, traditional site survey has limited potential and the most promising strategy is the location of palaeosols with evidence of human activity based on soil analysis and palaeobotanical studies.

Sedimentology from a dozen deep cores is providing invaluable information on the environments that early human populations in the area would have enjoyed or coped with. The cores testify to a highly dynamic river Cauca and its tributaries resulting in a series of rapid local environmental changes. Besides extensive periodic flooding, past populations were probably affected by tectonic events since numerous faults cross the region. Volcanic ash is a component of many of the soil cores but much was redeposited material from earlier falls, probably during the Pleistocene.
\end{abstract}

Direct archaeological evidence of human activity during the Early and Middle Holocene is limited to a mastodon skeleton with butchering marks on its ribs, and to a surface find of a stone 
tool $(a z a d a)$ characteristic of this period. Of the numerous fertile palaeosols detected in cores, some have agricultural characteristics and there is evidence of fires, possibly for clearing fields, from the late seventh millennium B.C. while by the third millennium B.C. a site provides evidence of burning in combination with the cultivation of maize (Zea mays) and arrowroot (Maranta arundinacea).

While a relatively large number of archaeological sites testify to human activity over much of southwestern Colombia during the Early and Middle Holocene, research has drawn attention to a period of archaeological silence between 2500-1000 B.C. when Formative societies were developing in other regions of South America. An important focus of this project is the search for traces of human activity during this period. The palaeosols have important potential for acquiring information on this question since stratigraphical evidence suggests that many lie within this time range. By the Late Holocene (c. 500 B.C.) the Ilama population was established in that region of the alluvial valley centred on Lake Sonso and the town of Palmira, followed by Yotoco and, further south, Malagana; in contrast, in the northern sector of the valley evidence for this sequence remains tentative. Here the only settlement site located so far with very late Formative characteristics produced an entirely new style of pottery. This site (first century B.C.) was in wooded marshland where houses must have been built on stilts, contrasting with Late Period sites (c. AD 500 - 1500), occupied by a sequence of different cultural groups of the Sonsoide tradition and located on slightly higher ground within the flood plain or in the piedmont.

Key words: archaeology, Cauca Valley, Colombia, environmental hazards, tectonic events, floods.

\section{Introduction}

The focus of this paper is to present a wide sweep of the information obtained on human occupation and the environment on the Cauca floodplain during the Holocene (Figure 1). Archaeological, palaeobotanical and lithological proxies are used. The research, summarised here, ${ }^{1}$ was initiated in 2008 , concentrating principally on two areas of the middle and northern sectors of the floodplain. The first of these areas, Lake Sonso, with the surrounding neighborhood,

\footnotetext{
${ }^{1}$ See, for instance, Cardale de Schrimpff et al. 2009, Cardale de Schrimpff et al. 2012, Duncan et al. 2013, Cardale de Schrimpff et al., 2015a, Cardale de Schrimpff et al., 2015b, Cardale de Schrimpff et al., 2016, Cardale de Schrimpff et al., 2017, Cardale de Schrimpff et al., 2018. The detailed results of our research in the first area of study, centred on the Laguna de Sonso, are to be published shortly in book form by the Fundación de Investigaciones Arqueológicas Nacionales del Banco de la República.
} 
is nearly $400 \mathrm{~km}^{2}$ in extension while the second, centered on the municipalities of Toro and La Union, covers a further $140 \mathrm{~km}^{2}$ (Figure 2).

A number of studies of the flood plain have focused on Sonso and Sonso-related sites of the Late Period (e.g. Rodriguez 2002, Herrera 2005, Gähwiler 2005, Bray 1971, Patiño et al. 2004) and, to a lesser extent, the Late Formative sites of the Ilama, Yotoco and Malagana societies (e.g. Bray 1971, Bray 2005, Bray et al. 2005, Rodríguez et al. 2007, Herrera et al. 2007, Cardale Schrimpff et al. 2012. However, there is still very little information available on human activities in this landscape for the earlier part of the Holocene. (Figure 3).

Throughout south-western Colombia there is a surprising scarcity of evidence for human presence during the period of some two thousand years (ca. 3000-1000 B.C.) when Formative societies are developing in other regions of South America. CITA An important aspect of this project is the search for traces of human activity during this period. A further point to clarify is the degree to which the territories of the Ilama and Yotoco societies extended towards the northern sector of the floodplain and their degree of interaction with the neighbouring Classic Quimbaya. The department of the Quindío appears to have been the southernmost extension of this society and here pottery vessels which are clearly Yotoco in style have been found in some of the richest Classic Quimbaya tombs (Pérez de Barradas 1966). Furthermore, a number of less sumptuous burials with Yotoco grave goods have been found near the site of the present Armenia airport (Pro Calima, unpublished archives).

Our current knowledge of the cultural chronology for the northern part of the valley is summarized in Figure 3. Our research is making it clear that the earliest populations of the flood plain were contemporary with species of megafauna while soil studies, coupled with palaeobotanical analysis, have detected evidence of extensive burning, possibly anthropogenic, as far back as the late seventh millennium B.C. (Duncan et. al. 2013). Dates from paleosols for cultivated plants currently go no further back than the middle of the third millennium B.C. but the abundance of stratified paleosols on the flood plain suggest that further analysis will provide substantial evidence for the tending of food plants from a much earlier period. Settlement sites of the Late Period are rather abundant in both areas of study; some evidence is emerging that, in the northern area of study, these populations and the Late Formative societies preferred contrasting environments for their settlements.

\subsection{General setting of the study area}


The river Cauca rises in the mountains of the department of Cauca and, for a distance of some 200 kilometers runs through a broad alluvial plain. This varies in width between fifteen and thirty kilometers. At an altitude of between 950 and $1000 \mathrm{~m}$, the temperature is sub-tropical (with an annual average of $24^{\circ} \mathrm{C}$ ) and the climate bimodal, with two pronounced dry seasons from late December to March and from June to September. Annual precipitation values are of approximately $1000 \mathrm{~mm}$, varying slightly from south to north.

The regional vegetation of the study area is classified as Dry Tropical Forest (Diaz Merlano, 2006; Atlas de Colombia 1977, 91). Some of the more characteristic trees on the floodplain are the ceiba, (Ceiba pentandra), several species of Annonaceae, the caracoli (Anacardium excelsum), the totocal (Achatocarpus nigricans) and the nacedero (Trichanthera gigantea). Palms are an important feature of the vegetation and include the corozo (Aiphanes aculeata), the corozo de puerco or wine palm (Attalea butyracea), the sancona (Syagrus sancona) and the palmicha (Sabal mauritiaeformis), traditionally used for thatch. Stands of bamboo (Guadua angustifolia) are still common, particularly near water courses. Several species of tree such as the burilico (Xylopia ligustrifolium) populate areas liable to prolonged flooding and can resist these conditions for eight months and more. On the lower regions of the valley slopes the xerophytic vegetation includes thorny shrubs and low trees such as the aromo (Acacia farnesiana) and the tachuelo (Zanthoxylum sp.).

The soils are some of the most fertile in the world (Instituto Geográfico Agustín Codazzi, 2004). Cattle ranches and small farms are now largely replaced by fields of sugar cane on an industrial scale although much of the northern part of the valley is an important fruit-growing area. Most of the extensive lakes, marshes and oxbow lakes reported in the nineteenth century (e.g. André,1883) were still extant at the beginning of the last century with their almost legendary offer of fish and game.

This abundance and variety of species of mammals, birds, reptiles and fish would have contrasted sharply with the situation in the forests of the surrounding mountains and would have provided a powerful attraction to populations during most of the Holocene. The edible common snapping turtle (Chelydra serpentina) is still found occasionally in the oxbow lakes and is reported to reach weights of up to 35 kilos while travelers accounts from the nineteenth century describe herds of peccaries (Pecari tajacu or Tajassu pecari, André, 1883: 125) feeding on the fruits of the burilico trees (Xylopia ligustrifolium) at the margins of the flooded forest. Among other animals, 
the floodplain was also home to herds of deer (Cieza de Leon, 1962 [1555]: Chapter XXVI, 113). Of the 162 species of birds registered for the Laguna de Sonso, the largest lake remaining on the floodplain (Alvarez-López, 1999), two species of whistling duck (Dendrocygna bicolor y D. autumnalis) are particularly prized for their meat while edible species of fish in the rivers include the dorada (Brycon morei), sabaleta (Brycon sp.), a freshwater catfish, bocachico (Prochilodus magdalenae), beringo, and dienton (Hoplias malabaricus). When the river is in flood, some of these species such as the bocachico, guabino (Trichomycterus caliense), sardina (Microgenys minutus) and bociancha (Genycharax tarpon) are able to travel to the neighboring ciénagas, in the recent past, as many as 80 or 90 bocachicos could be taken with one cast of the net (atarraya).

\section{Methods and Strategies}

The palaeoenvironmental approach is gradually being seen, in many parts of the world, as a key to obtaining information on the past when, for various reasons, it is difficult to locate ancient occupation sites (for example, Siegel et al. 2015). In this project the research is conducted by a team of archaeologists, palaeobotanists and a soil specialist. A first step was the construction of a map of each research area, with the geomorphology of the Floodplain of the river Cauca, the Alluvial Plains bordering the Piedmont, as well as the Recent and Sub-Recent Piedmont. The maps were based on those available from the Instituto Geográfico Agustín Codazzi and air photographs, with particular reliance on the oldest flights available before the valley had suffered extensive anthropic modification. Each of these landscapes were surveyed for archaeological material visible on the surface.

Nearly 100 cores were taken for soil and palaeoecological studies (fossil pollen and phytoliths) at sites carefully chosen for their information potential. For cores for pollen samples, the few remaining lakes and marshes were sought. Those profiles exposed in river banks which revealed palaeosoils were explored and cored to obtain samples at greater depth. In addition, points where later prehispanic materials were found in the course of our field surveys or as a result of information from local inhabitants, were cored in the hope of finding earlier material beneath. These cores were obtained using an Edelman auger with extensions of up to six meters and with different heads for varying soil conditions. In addition, 5 deeper cores of up to $11 \mathrm{~m}$ in depth were recovered using a mechanical auger. Road cuts are relatively rare in this landscape and stratigraphic information from the banks of streams and the river Cauca was particularly valuable. 
Additionally, a total of seventeen deep exploratory trenches were excavated in the different landscapes at points where the initial cores had revealed a particularly interesting stratigraphy. These generally measured $3 \times 1.5 \mathrm{~m}$ with a depth of up to $4 \mathrm{~m}$, depending on the soil conditions and the water table. In the field, the characteristics of the different soil horizons (principally colour and texture), provided us with a considerable amount of information about the history and environment of the different physiographic landscapes and the changes in local conditions and vegetation throughout the Holocene. Every horizon provides evidence of the conditions under which the human population lived at any one time.

The soil samples were analyzed, principally, for phosphorus ( $\mathrm{P}$ total). This is a relatively economical analysis and, since human activity usually leads to increased levels of phosphorus in the soil, it can be a valuable indicator with different levels suggesting settlement sites, agricultural soils or garden plots. It is also a pointer to decayed organic matter such as human burials or the skeletons of large animals. Where funds permitted more extensive analyses were made, including calcium, magnesium and potassium, following the standard for characterization laid down by the Colombian Instituto Geográfico (IGAC). These latter analyses are particularly important for indicating the agricultural potential of paleosols and their suitability for particular crops.

For pollen analysis, samples of $1 \mathrm{~cm}^{3}$ were prepared using the standard treatment of sodium pyrophosphate, acetolysis mixture, and heavy liquid separation by bromoform (Faegri and Iversen, 1989). For pollen identification we used the pollen reference collection of the University of Leicester's palaeoecology laboratory and photo plates published by Hooghiemstra (1984), Roubik and Moreno (1991) and Herrera and Urrego (1996). The software Tilia and Tilia Graph was used to plot the pollen diagram (Grimm, 1990). Results of phytolith analyses discussed here were previously published in Duncan et al (2013).

\section{Results and Interpretation}

\subsection{Environment and Human Activity during the Late Pleistocene.}

The time frame for the cultural and environmental development of the area is anchored by a series of eleven radiocarbon dates stretching from the Upper Pleistocene to shortly before the Spanish 
Conquest $^{2}$ (Table 1). The earliest radiocarbon date $(25445-25215$ cal. BC) for a well-defined palaeosol from the bottom of the El Nilo core $(1360-1410 \mathrm{~cm})$ is indicative of sediments deposited prior to the Last Glacial Maximum (Figure 4, Map Figure 5). There is no association with fauna or human activity, the level of organic material in the sample was low and acceptance of the date is provisional for the time being. The characteristics of the soil (the color ${ }^{3}$, coupled with the low level of organic material) indicate relatively dry conditions; the content of total $\mathrm{P}$ is relatively high (408 ppm). JUAN CARLOS - IBAS A BUSCAR UNA BUENA CITA!

The earliest evidence for human activity in the region is the skeleton of a mastodon, part of which is preserved in the museum of the Casa de la Cultura in Toro. The skeleton was discovered some 35 years ago in the bed of the river Cauca, by Adolfo Quintero and his family, while fishing at a time when the water in the river was at an exceptionally low level. Found, together with an ivory artefact carved from a tusk, the discovery has been referred to in a number of publications (e.g. Rodriguez 2002). A recent examination by Carlos López, Martha Cano and Anthony Ranere (personal communication, 2015) detected cut marks on some of the ribs, left by the ancient hunters when butchering the animal (Figure 6).

Since the river Cauca is constantly changing its course, we can be almost certain that it was some distance away at the time when the mastodon died and the characteristics of remnants of soil recovered close to the skeleton suggest that it was hunted in a marsh, a favorite haunt of these animals. The skeleton has not been dated but since mastodons were still present in northwestern Colombia in the late Pleistocene and well into the Early- and Mid-Holocene (Correal and van der Hammen, 2003), this example may have met its end at any moment during this long period. It is not the only mastodon skeleton known from the area: two further examples are reported from the

\footnotetext{
${ }^{2}$ Reimer, PJ, Bard, E, Bayliss, A, Beck, JW, Blackwell, PG, Bronk Ramsey, C, Buck, CE, Cheng, H, Edwards, RL, Friedrich, M, Grootes, PM, Guilderson, TP, Haflidason, H, Hajdas, I, Hatté, C, Heaton, TJ, Hoffmann, DL, Hogg, AG, Hughen, KA, Kaiser, KF, Kromer, B, Manning, SW, Niu, M, Reimer, RW, Richards, DA, Scott, EM, Southon, JR, Staff, RA, Turney, CSM \& van der Plicht, J 2013, 'IntCal13 and Marine13 radiocarbon age calibration curves 0-50,000 years cal BP' Radiocarbon, vol. 55, no. 4, pp. 1869-1887. DOI: $10.2458 / a z u \_j s \_r c .55 .16947$
}

\footnotetext{
${ }^{3}$ The color (10YR 3/3, dark brown) is not indicative of intensive weathering. For this to take place more humid conditions are necessary and the horizon would have a yellower or redder color.
} 
neighboring municipality of La Victoria (Cardale de Schrimpff et. al. 2015) while Rodriguez Flórez et al. (2009) summarize information for a number of other finds on the alluvial plain.

No new examples were located in the course of this project. However, at the Cauca 3 site (Figures 7 and 8) located on the river bank some 100 meters upstream from the point where the Toro mastodon was found, the level of phosphorus in three horizons was extraordinarily high ( $\mathrm{P}$ total of 1215,1760 and 2185 ppm respectively) which must be due to some out-of-the-ordinary factor or event. A possible explanation might be the decomposition of the bodies of very large animals of the size of mastodons that may have died there. The stratigraphy at Cauca 3 suggests that these horizons may be relatively close in time to the period in which the hunted mastodon lived. The characteristics of the soil horizons at this site, between approximately 10 and $6.50 \mathrm{~m}$., indicate constantly changing conditions in a landscape of lakes, swamps and woodland, well suited to large herbivores such as mastodons. Undoubtedly the presence of herds of these animals would have attracted bands of hunters like those who killed the Toro example.

\subsection{Environment and Human Activity during the Early to Mid-Holocene (c. 8000-2500 BC)}

With the wealth of game available, there is clearly no reason to suppose that the area would have lost its appeal to humans after the disappearance of the megafauna but during the Early Holocene, the activities of hunting and fishing left little detectable evidence. At the same time, the abundance of burnt phytoliths in a sample dated to Cal. 6230-6060 B.C. may indicate some sort of human impact on the environment (Duncan et al. 2013, 166), whether for clearing the ground or as a tactic used in hunting. The sample comes from a marshy palaeosoil at a depth of 742-750 $\mathrm{cm}$, in a core taken at the Yotoco Ferry site. The dates for the horizons above this are confusing and suggest periods of erosion and mixing. Maize phytoliths and one squash phytolith are found in three of these horizons but, due to the probability of mixing, we can only be sure that these phytoliths predate the Ilama-Yotoco level. However, it is worth bearing in mind that, in the neighboring mountains, starch grains from the sites of La Selva and El Jazmin indicate the use of local root crops (Dioscorea sp. and Calathea sp.) by 6660 B.C. while manioc was introduced into the region ca. 5590 B.C. By 5080 B.C. there is evidence that maize was being grown (Dickau et al. 2015).

It is important to remember that the same conditions once found on the flood plain (a food supply sufficiently abundant to allow human populations to become sedentary and fertile soils 
where tended plants can flourish) are those considered by Sauer (1952) and later endorsed by Piperno and Pearsall (1998: 19, 74) as particularly suited to initial experiments with crops.

\subsubsection{Plants and People.}

Evidence for plant related activities in the neighborhood is provided by the find of a stone hoe (Figure 9) from the Recent Piedmont that borders the flood plain. This instrument, from the vereda of San José de los Osos, is a surface find but is a type fossil characteristic of the Early-and Mid-Preceramic in much of southwestern Colombia (Herrera et al. 1992; Herrera, Moreno and Peña 2011: 28-29; Aceituno and Rojas 2015, Arroyave et al. 2018) which appears to have been used to dig the soft alluvial or volcanic soils to harvest edible roots and tubers and, possibly, in connection with an early form of horticulture.

The series of long profiles visible today on the banks of the Cauca (e.g. Figure 8), complemented by the auger cores, indicate an extremely dynamic river which has constantly changed its course in a landscape of dikes, basins, lakes and marshes suffering constant modification. In the deep core from Cauca 3 (of $1140 \mathrm{~cm}$ ) it is possible to detect at least seventeen changes of this sort, a dozen of which took place during the last nine thousand years. It is clear from this that any human populations living on the flood plain would have had to endure periods of flooding and of drought but, except in years of extreme conditions, they would have learnt to live with these conditions.

The analysis of fossil pollen from the Cauca 3 site (Figure 10) shows the most relevant ecological groups and associated pollen taxa and in Table 2 the results of the pollen analysis are compared with the lithological information. The vegetation is not only indicative of open grassy areas but also the presence of the floating horsetail grass (Paspalum sp.) transported by the Cauca river. The abundance of grasses is preceded by swamp vegetation, towards the bottom of the pollen record, with Cyperaceae, Typha and Polygonum indicative of wetter conditions. Previous to this, lithology and pollen indicate woodland (Figures 7, 10 and Table 2).

The grasses, indicative of open areas, become important between $650-550 \mathrm{~cm}$, and may be related to early human activities in the area. Evidence of cultivars (Zea mays) and disturbance (Amaranthaceae/Chenopodiaceae) appear around this point. Lithologically the horizon is a clay soil with agricultural characteristics; it is interesting that it developed on a marsh which had gradually dried out. The coprophilous fungi support the evidence for disturbance, with 
Coniochaeta indicative of settlement activities (Cugny et al. 2010). The regional vegetation continues to be important with pollen from Subandean and Andean forests. This palaeosol is still undated but it is three meters above another buried soil which is dated to 7060-6905 cal. BC (Table 1). Over a meter of the intervening horizons are lake sediments which suggest a slow and gradual formation for this part of the core and the possibility of a mid or late preceramic age for the maize pollen. From 550 to $455 \mathrm{~cm}$, there is a gap in the pollen information, due to poor preservation and sedimentation of silt from the Cauca river.

A second group of pollen samples from the Cauca-3 pollen diagram $(450-350 \mathrm{~cm})$ show some evidences of river pulse with periods of flooding, as shown in the segment above with Cyperaceae indicating wetter periods (Behling and Hooghiemstra 2000), but also with development of gallery forests. On the river banks Cecropia, a fast-growing pioneer, associated with woody shrubs from the Urticaceae/Moraceae families, would have helped to stabilise the river banks with their natural dikes and protect them from erosion as suggested by the presence of Glomus in parts of the pollen record. Other taxa such Acalypha, Bignoniaceae, Myrtaceae and Piper are important elements of the gallery forest. During this period, there is little evidence for human impact in the pollen diagram. Although Cecropia in combination with similar vegetation composition appears to be indicative of human impact in other Colombian records, this does not appear to be the case here (Bakker, 1990; Behling et al., 1998; Wille et al, 2000; 2001; Berrío et al. 2002).

The upper section of the pollen diagram shows evidences of recent, strong human impact. Few arboreal pollen taxa are registered in the pollen record, with some Poaceae and shrubs such Asteraceae and Gomphrena appearing scattered in the open landscape. Ambrosia as well as some species of Amaranthaceae/Chenopodiaceae are human disturbance indicators (Rull et al. 2005) and are also found as weeds in agricultural fields or plots (Chepstow-Lusty et al. 1998; Kuentz et el. 2012) as is confirmed here by the presence of Zea mays representing recent and contemporary agricultural activities. These taxa relate well with the rather high levels of coprophilous fungal spores such as Coniochaeta, Sporormiella and Rivularia, indicative of large-scale pastoralism near the coring site (Kiage and Liu, 2009). The spore Rivularia (Cyanobacteria) is an algae indicative of a nutrient rich environment (Revelles and van Geel, 2016).

Additional information on developments in cultivation on the flood plain remains sketchy but a little south of the Laguna de Sonso, analysis of phytoliths from palaeosols appear to indicate 
increasingly intensive land-clearing practices associated with agriculture some time before 24802290 Cal. B.C. (Duncan et al. 2013: 168). For the Toro area soil studies have detected numerous palaeosols, some of which appear to have agricultural characteristics. Many of them are at depths of between approximately 1.0 and 2.5 meters; the available dates do not show a clear correlation between depth and age due, no doubt, to the different rates of accumulation of sediments in varying circumstances. However, it seems likely that many of these soils were in use during part of the last 2000 years and possibly before.

\subsubsection{Evidence for climate and environmental change}

Evidence is accumulating for some rather abrupt changes to the environment in general to which, in addition to serious flooding, past populations would have had to adapt. A river floodplain is probably not the place to look for evidence of climate change since many of the variations in soils and vegetation documented in the cores are almost certainly highly local, the result of the position of the river and its adjacent landscapes of dykes, basins and wetlands changing through time. However, soil and pollen studies document the vegetation history of the Laguna de Sonso during much of the Holocene (Berrio 2012, Duncan et al. 2013: 162-4; Cardale de Schrimpff et al. 2012). These indicate drier and wetter periods with phases of invading and retreating woodland on the lake bed which may indicate regionalised changes in precipitation rather than merely local events .

Evidence for periods of stability alternating with abrupt change are suggested by the Higueroncito site (Figure 11) in the Subrecent Piedmont. Here a stream or small river cut through a colluvial-alluvial terrace to a depth of eight meters, revealing a long sequence of palaeosols separated by horizons of stones and rubble which accumulated in periods of environmental instability. A similar sequence was revealed in a small excavation on the nearby terrace (Figure 12). The stream bank sequence covers a period of 5500 years with a radiocarbon date from near the base of 3500-3425 cal. BC (Table 1). The sequence studied starts from a thick deposit $(90 \mathrm{~cm})$ of volcanic ash, interpreted originally as fall from an eruption in the Central Cordillera at some point during the fourth millennium BC. However, a recent investigation by geologists concluded that the ash was redeposited material, originating from an earlier source not yet identified (Monsalve and Toro, 2016). 
The abrupt slopes of the piedmont are subject to frequent landslides today due partly to the terrain and partly to the generally sparse vegetation. A further hazard, both in the piedmont and on the floodplain, is the result of the many fault lines that cross the area (Instituto Colombiano de Geología y Minería INGEOMINAS, Planchas Geologicas 242 y 223, 1992/2009) which must often have caused dramatic local modifications of the landscape. A possible tectonic event appears to be documented in the central section of the El Nilo core where a predominantly dry floodplain landscape is transformed into a depression filled with a series of wetlands which became extensive lagoons in times of flood.

\subsubsection{Settlements on the different physiographic landscapes}

Evidence for human settlements or other activities was detected in all the different physiographic landscapes in both our areas of research. This section describes, principally, the northernmost areas. Here almost all the evidence found so far has been for the Late Period (from ca. A.D. 600 until the Spanish Conquest). While it is possible that this reflects a considerable increase in the population at this time, we should beware of assuming this without taking other factors into consideration. Late Period sites are much easier to locate since there has been less accumulation of river sediment or slope wash to cover them and, at the same time, more erosion as a result of recent agricultural activities with deep ploughing and areas of bare soil.

Since the research covered areas of approximately $400 \mathrm{~km}^{2}$ and $140 \mathrm{~km}^{2}$ respectively, it was not possible to explore the different landscapes in detail and even less feasible to quantify or compare numbers and characteristics of these different sites according to the landscape in which they are found. It is clear that the river Cauca floodplain was fairly heavily populated during the Late Period, at least at certain moments and at particularly favorable spots. These include places such as Rancho de Paja, which was located a few meters higher than the rest of the floodplain and so generally remained above the floodwaters, or like the seasonal lake at El Nilo around which at least five different settlements have been documented as well as a number of (plundered) graves. On the alluvial plains bordering the piedmont, five sites were located as well as two in the recent piedmont and only one in the sub-recent piedmont.

The low figures for these last two landscapes may perhaps be explained by the extensive areas covered by a dense and thorny xerophytic vegetation. On the other hand, this xerophytic vegetation does not cover the whole of these physiographic landscapes. In two places which would appear to be especially attractive for human settlements, the colluvial-alluvial terrace cut by the 
quebrada Higueroncito in the sub-recent piedmont and, in the recent piedmont, the wide alluvial terrace bordered by the lower stretch of the quebrada La Chica above Toro, we have so far been unable to find pre-Hispanic cultural material or information regarding archaeological finds.

The final landscape in the area is the Western Cordillera which we only visited on two brief occasions. Here, in contrast, numerous artificial house platforms or tambos, cut into the hillsides, can be easily recognized on the grassy slopes and the scarce information available suggests that they were constructed both during the Late Period and earlier.

\section{Environment and Human Activity during the Late Holocene (2500 BC hasta AD 1550)}

The beginning of the Late Holocene period coincides with the start of the period of Archaeological Silence. The only conclusive evidence we have for human activity at this time is that from the Cienega de Vidal site, mentioned earlier, where evidence for crop cultivation is associated with increasingly intensive land clearance. After this there is, currently, no further evidence for human activity in the region for the next 1500 years until the advent of the Late Formative societies. In the southernmost of the areas studied, the Ilama society appears to have been present for much of the first millennium $\mathrm{BC}$, evolving gradually into the Yotoco and Malagana societies. Further north, however, information on this part of the period remains somewhat elusive.

\subsection{The Late Formative societies of northern sector of the Cauca valley.}

Since one of the objectives of this project was to establish the presence, or possible absence, of the Ilama and Yotoco cultures in this part of the valley, a considerable amount of time was spent in searching for possible sites. Although there are hints of at least a Yotoco presence in the region, so far these are limited to a few sherds excavated by Moreno, Briceño and Quintana (1991: 69-71) and a grave discovered by accident some thirty years ago, which contained a number of gold objects, some of which are identical to examples found in Yotoco graves in Calima (Cardale de Schrimpff et al. 2015).

While we have, so far, been unable to locate either settlements or graves of either the Ilama or the Yotoco societies in the northern region of the alluvial valley, this may be due to the very rapid rate of sedimentation on the Cauca floodplain, already mentioned. The apparent absence of these sites is in contrast to the situation in the central region of the valley where Ilama and, especially, Yotoco settlements are relatively numerous (Cardale de Schrimpff et al. 2012). 
However, here too they proved difficult to locate initially and their extent and importance has only become evident fairly recently.

Taking advantage of the exceptionally low level of water in the river Cauca during the drought of late 2015, we were able to examine recently exposed sections of the river banks from a canoe. Several additional Late Period sites were documented and, at El Paso (Figure 13), a settlement site on a temporary "beach" proved to have pottery of a style that was notably different from that of either Ilama or Yotoco as well as being distinct from the styles of the Late Period (Figure 14).

In a brief visit to this site we were able to collect a sample of pottery and other materials. A radiocarbon date for the cultural level (Beta 422629: Cal. 155-135 AC y 115 AC - 25 D.C.) suggests that it is contemporary with the period of transition between Ilama and Yotoco in other parts of the valley. The style of pottery is not represented in the collections of the Casa de la Cultura in Toro nor does it appear to have exact parallels in other museum collections. At the same time, it does share a number of features with the pottery of contemporary cultures: the way of depicting the hair by means of parallel vertical incisions on the little, solid figurine is similar to representations of hair on Ilama figures. Parallels for the features on the anthropomorphic, doublespouted vessel (alcarraza) can be found on some figures from Malagana while large spindle whorls made of green stone, like the broken example on the left in the same figure, are known elsewhere only from sites of the Malagana culture (Herrera, Cardale de Schrimpff and Archila, 2007: 66, Figures 51 y 52).

There is a striking difference between the environment of this site and the environments preferred during the Late Period when, as mentioned above, the sites were usually located at slightly higher points within the floodplain at places that would be less affected by flooding. In contrast, the former inhabitants of El Paso were living in a marsh, among large trees of species that were able to resist long periods of water-logging. The houses would have had to have been built on stilts. Figure 15 illustrates a tentative reconstruction of the formation and history of the site and the reasons for its abandonment. A diminutive fragment of a very finely meshed net, preserved at this site, suggests the importance of fish in the diet of the inhabitants and it is clear that they must have been accustomed to a way of life among lakes and marshes where the canoe would have been an indispensable form of transport. In this aspect, too, they were similar to the inhabitants of the site of Malagana, lords of the lakes and marshes. However, more than a society 
related to Malagana, the inhabitants of El Paso appears to have been a society adapted to a similar way of life. Given the conditions on the floodplain of the river Cauca at this time, we should expect to find similar societies that adapted in this way.

4.2. The various different occupations during the Late Period (ca. A.D. 600 until the Spanish Conquest).

Almost no archaeological research had been carried out in this part of the alluvial valley prior to the start of our project but, based on our own observations, local information and the collections of the Casa de la Cultura in Toro, we have been able to identify at least four different pottery styles in the area during this Late Period (Figure 16). There are marked differences between the pottery found between one site and another, although these styles all share features characteristic of the general and geographically widespread Sonsoide Tradition. They appear to represent occupations by distinct but related populations or societies at different times during this period or, at least, different stages in the development of these societies. Our information is still in the initial stages but comments by local inhabitants suggest that the variations in pottery styles are accompanied by differences in grave types and burial customs, as well as in the variety of gold and tumbaga jewelry buried with the dead. There also appear to be some differences in the physiographic landscapes favored by the different groups. These variations are hardly surprising since we are dealing with a period of some eight or nine centuries.

Since the focus of our research project was principally on the earlier periods, we were unable to devote as much time to the Late Period as it deserves. The cultural remains from these sites are generally much closer to the surface than those of earlier periods and so are much easier to find. Over a dozen sites were discovered in the course of field walking or as the result of local information. Since a number of these sites were located at particularly advantageous points, usually on slightly higher ground, we tested a number of them with a soil auger in the hopes of finding evidence of earlier occupations at the same site at greater depths.

The most recent pre-Hispanic population in the area was that responsible for a pottery style which we have called "El Guachal", after the area where it was first studied. It is still clearly within the Sonsoide tradition and a radiocarbon date is now available of Cal. 1285-1395 D.C. (Beta 414457). The "type fossil" of this style is a very distinctive large anthropomorphic jar (Figure 16, C) characterized by a plump body and a face modelled on the neck of the vessel with an expression 
that varies from satisfied to smug. The most important feature of the face is a prominent aquiline nose. The other features are unimportant by comparison: the eyes are rather swollen and of the coffee-bean type, the ears are very small while the diminutive mouth is almost entirely hidden beneath a nose ring that is invariably of the type known as "torzal", represented as a twist of thick wire. Two small excavations at the site of La Colonia together with the information we were able to collect on the neighboring cemetery, discovered some twenty years previously, has enabled us to piece together a considerable amount of information on this occupation.

Pottery of the Guabas-Buga style appears to be found rather frequently in the region: Moreno, Briceño y Quintana (1999: 69-77) report it from the majority of the sites they excavated or where they made surface collections and there is a considerable number of these vessels in the collection of the Casa de la Cultura (Figure 16, B). The style comprises a wide variety of pottery forms: particularly characteristic are rather large cylindrical vessels with two sets of opposing handles (Rodriguez 1989, Figure 1: 5,6; Bray 1989: Figure 7; Figure 8: 11,21).

First identified as a style by Bray and his team in 1964, the style has intrigued many archaeologists both because of its distribution over an extensive area and from the point of view of its relationship to other Late Period cultures. Whereas most Late Period cultures, although within the Sonsoid tradition, are very local, this style is found over a distance of some $180 \mathrm{~km}$ from north to south (from near Manizales in the north as far as to the south of Buga).

Burial customs, even at the larger cemeteries such as Guabas and Buga, appear to have been relatively unstandardized although shaft and chamber tombs of various shapes and depths appear to have been the preferred form and burials were predominantly primary. In some cases the pottery found as grave goods appears to have been exclusively or largely of the Guabas-Buga style while in other cases it was mixed with other, local, styles. Radiocarbon dates for the style cover a rather wide time range. Rodriguez suggests that the Guabas culture flourished between the seventh and twelfth centuries A.D. with Buga between the fourteenth and sixteenth centuries (1989: 81, 87). ${ }^{4}$ Bray, on the other hand, proposes a shorter chronology covering, 'principally, the Xth to XIIth centuries with occasional dates from the previous century.

Recent information from the Aeropuerto del Café excavations near Manizales document occasional finds of Guabas-Buga vessels in graves of the Palestina period, the penultimate pre- 
Columbian occupation of the area which dates from between the VIIth and early XIth centuries A.D. (Herrera et al. 2011: 40-41). This situation would seem to be corroborated by that in the Toro area where Guabas-Buga material is absent from sites of the El Guachal period and so here too must also be prior to the final pre-Columbian occupation of the region.

Among the other two populations that once inhabited the area is the society responsible for the "retablos", solid anthropomorphic figurines constructed from slabs of clay, which are very common in museums and private collections (Figure 16, A). They are also items that have been copied frequently and fakes abound. In our region of study we have occasionally found fragments of these figurines during field-walking and reports suggest that graves with this type of figurine are relatively common, both on the floodplain and in the neighboring mountains; in some cases, between ten and twenty of these items are reported from a single grave.

The "cocos", another type of anthropomorphic figurine, appear to be related stylistically but, as far as we have been able to ascertain, they are not found in the same graves as the "retablos". As their name implies, they are hollow rather than solid. Almost no reliable archaeological information is available for these two styles, both of which, like the El Guachal style, appear to be restricted to a very small area.

At present the relationship between these two styles is unknown and there are no clues as to which of the two preceded the other, whether they were earlier or later than Guabas-Buga or even if they were contemporary populations occupying different physiographic landscapes. There are no osteological studies or even collections from the area of our research which might indicate the degree of continuity or lack of it between the different populations. However, in the neighboring municipality of Obando, a study of the material from the Late Period cemetery of Dardanelos revealed interesting changes in the physical aspects of the population buried there during the seven centuries when the cemetery was in use (Rodríguez Flórez 2003).

\section{Discussion}

The new archaeological information derived from our recent research outcomes has given us more clues to understand that the floodplain of the Cauca valley has a long history of human activities in the area throughout the Holocene and probably earlier (Berrio et al. 2002; Rodríguez 2002; Cardale de Schrimpff et al. 2005). This contrasts with the interpretations, current for many years, when the evidence of human activities dated mainly from the Late Period while, previously, 
it was even suggested that the floodplain may have been unsuited to human habitation (Ford 1944: 12). The realization that there were settlements in the area before the Late Period was first due to the field work of Bray and his team (Bray and Moseley 1971) and then to the chance find of the Malagana site (Bray et al. 2005). However, the evidence went no further than the first millennium BC.

The cultural history of this region can now be traced as far back as the hunters of big game when mastodons roamed the floodplain, making it a very attractive hunting ground for human beings. However, with the wealth of other game available, there is clearly no reason to suppose that the area would have lost its appeal to humans after the disappearance of the megafauna. Since the hypotheses of Gerardo Reichel-Dolmatoff (1986: 67-9) for the Formative populations of the rivers and lakes of the coastal lowlands of northern Colombia, the importance of environments of this type for early pre-Columbian populations has been evident. He suggested, furthermore, that these landscapes of rivers and ciénagas were an ecological niche where animal protein was so abundant that sedentary populations could subsist without agriculture or with merely a rudimentary degree of horticulture. The preference of prehispanic populations for settling near lakes or marshes, even when these are relatively small, is evident in many other regions of the country. This is the case from the Sabana de Bogotá with sites such as Aguazuque, to Calima where places with these characteristics were sought out by the Ilama population. The floodplain of the Cauca valley would have borne a closer resemblance to the north coast, although on a much smaller scale. It is interesting that, by the first millennium B.C., one of the wealthiest societies to inhabit the valley chose, at Malagana, a riverine site bordered by marshland.

It has been argued that burnt phytoliths at a depth of 724-750 $\mathrm{cm}$ from the Yotoco Ferry core are dated to the late seventh millennium BC (Duncan et al. 2013: 166) and may indicate human impact on the environment this time. The presence in this sediment of a number of small stones with angular edges (rather than the rounded edges found on water-borne stones) suggests that they may have reached the site as a result of human activity. Burnt phytoliths associated with maize and squash in strata above $750 \mathrm{~cm}$ to $334 \mathrm{~cm}$ strongly suggest cultivation practices in this region at least as early as the sixth millennium BC. Another clue to human presence in the Early to MidHolocene is provided by a surface find of a stone hoe of a type characteristic of this period. A little later, phytoliths from the Vidal site (at the very edge of the floodplain), indicate the cultivation of maize and arrowroot some time prior to 2480-2290 cal. BC. while shortly afterwards, at the same 
site, burnt phytoliths of grasses and some species of trees are interpreted as land clearing by fire for cultivation (Duncan et al. 2013: 167-8). Cores at a number of points on the floodplain itself have recovered paleosols with agricultural characteristics, the deepest of these at a depth of 600$550 \mathrm{~cm}$ at the Cauca 3 site with maize pollen and evidence of disturbed vegetation. Although our evidence is fragmentary, it seems highly likely that the floodplain, with its benign climate and exceptionally fertile soils, will have played an important role in crop manipulation and cultivation.

The environmental history is documented by soil studies and palaeobotanical analysis of a number of deep cores. Early in the Holocene, lakes and marshes appear to have been particularly extensive, while towards the north of the Cauca River this was ephemeral and shallow swamps and seasonal lakes developed during the middle Holocene (Velez et al. 2013). Our recent studies indicate that the river Cauca has been dynamic throughout the Holocene and, in general, the palaeobotanical reports indicate local conditions resulting from this dynamism rather than regional climate change. However, the evidence for the invading and retreating woodland in the bed of the Laguna de Sonso is probably a more reliable indicator of generalized alternating drier and wetter conditions. Even here, however, anthropogenic forest clearance and subsequent erosion (like that documented for the Vidal site during the mid to late third millennium BC), if extensive, would have affected the catchment area and, with it, the level of the water in the lakes.

Studies of soils revealed in the banks of the river Cauca in the Laguna de Sonso area indicate a prolonged dry period, evidenced by the characteristics of some $2 \mathrm{~m}$ of sediment (Duncan et al. 2013, Cardale de Schrimpff et al. 2012). This dry period ended soon after 1000 BC and, so far, no evidence for human activities has been found in this horizon. By this time, conditions became more humid and a paleosol formed. This paleosol has been detected intermittently, exposed in the banks of the river Cauca, over a distance of more than $20 \mathrm{~km}$ and it is on this soil that the first Ilama and Yotoco settlements are found.

It is not clear how long the dry period lasted or when it began but the evidence from the Vidal site indicates moist conditions initiating some time before 2480-2290 cal. BC and lasting for at least a number of centuries (Duncan et al. 2013: 167-8, Cardale de Schrimpff et al. 2012). The evidence from this site may provide an upper limit for the dry period, suggesting that this endured for over a millennium. Further research is needed to confirm or disprove this hypothesis and the possibility that the period coincides with that of the "archaeological silence". 
It seems possible that this period of silence had rather different causes in different regions but was the result of destabilization and a general deterioration of conditions for human populations over a very extensive area of southwestern Colombia. In at least some cases, the "silence" coincides with a period of severe volcanic activity. For the northern area of the department of Tolima Salgado (this volume) refers to the effects of intensive activity of the Cerro Machin volcano between 3000 and 1000 BC. To the north, for the department of Caldas, Herrera et al. (this volume) has incontrovertible evidence for a rather large preceramic population during the Early Holocene, followed by a period of total abandonment. This was due to the eruptions of the neighboring volcano, the Nevado del Ruiz, which deposited a thick mantle of volcanic ash over the region and rendered it unfit for human habitation. Further north, in the department of Antioquia, a period of silence has also been detected (Aceituno 2017: 24-28) but here it was considerably shorter and rather more recent, starting about $1000 \mathrm{BC}$ and lasting for approximately six hundred years. The stone tools, in extensive regions such as the valley of the river Porce, are similar in range and technology to those found on sites in the Middle Cauca region; however, here at about 3000 BC, the preceramic population adopted pottery (the Cancana style, Aceituno 2017: 28-29) and continued to inhabit the region for a further 2000 years. So far there are no clues as to the cause of this silence in Antioquia, which ended with the arrival of a different and, apparently, unrelated population in the area somewhere about $400 \mathrm{BC}$.

For the pre-Columbian populations, hazards on the floodplain and in the neighboring piedmont would have included extensive flooding in the former area and frequent landslides in the latter together with tectonic events resulting from the numerous geological fault lines in the region. Evidence from the long profile at the Higueroncito site suggests periods of environmental stability alternating with periods of instability.

Although evidence for human activities was found in all the different physiographic landscapes in the Toro area, the settlements detected were almost exclusively of the Late Period, from between approximately AD 700 and the arrival of the Spanish. Although a considerable number were on the floodplain itself, as already mentioned they appear to have been located at slightly higher points within this landscape, out of the reach of the worst of the floods. The discovery of the earlier settlement at El Paso, in marshland surrounded by flooded forest, raises some interesting questions. Hitherto, although there had been hints of their presence, sites with 
Late Formative characteristics proved elusive. Did the people that lived at El Paso dwell exclusively in environments of this type? Or did they also inhabit the piedmont?

The fact that the site is dated to precisely the time of transition between the Ilama and Yotoco societies is also intriguing. Does this mean that Yotoco territory did not extend as far north as the Toro area? - a possibility that is still far from proven. One of the aims of this project was the retrieval of information on the northern limits of Yotoco territory and the interaction of this society with the Classic Quimbaya, both of which had an important presence in the Quindío, only $50 \mathrm{~km}$ further east. There is no evidence, so far, of Classic Quimbaya presence or influence in our research area.

The environmental characteristics of the El Paso site contrast with what we know of the contemporary Late Ilama and Yotoco sites on the floodplain further south; although opinions are not entirely in agreement on interpretation, the extensive settlement at the Barca de Yotoco, for instance, does not appear to have been situated in a marsh (Bray 2012). On the other hand, further south, the Malagana society does seem, in some instances, to have purposely sought out sites with these characteristics for their settlements as instanced by Malagana itself (Bray et al. 2005) and El Cerrito (Rodríguez 2005). That they did not, however, chose solely marshland sites as is indicated by the cemetery at Coronado (Herrera et al. 2007; Rodriguez et al. 2007). It is not, at present, clear whether the choice was based on cultural preferences, population pressure, or on environmental factors.

\section{Conclusions}

A picture is gradually emerging of a human presence on the Cauca floodplain since early in the Holocene and, possibly, the Late Pleistocene. The earliest incontrovertible evidence is the skeleton of a butchered mastodon discovered some years ago in the bed of the river Cauca. Soil studies have detected numerous palaeosols of different ages, some with agricultural characteristics, while palaeobotanical analysis documents arrowroot and maize in several soil horizons.

In the southern part of our research area, a dry period lasting a thousand years or more and ending at about $1000 \mathrm{BC}$ may coincide with and possibly explain the period of Archaeological Silence. No cultural material has been found, so far, in these sediments. An extensive palaeosol formed at the end of this dry period and has been detected in the banks of the river Cauca for a 
distance of over $20 \mathrm{k}$. It is on this paleosol that the settlements of the earliest pottery-using societies (Ilama and Yotoco) are found.

So far clear evidence for the presence of these two societies has not been found in the northern part of our research area. However, at the El Paso site a settlement with a very different material culture and environmental preference has been detected. A radiocarbon date indicates that it is contemporary with the Ilama-Yotoco transition in other areas of the valley.

Whereas the El Paso site was located in a marshy area, the settlements of the Late Period were situated on areas of marginally higher ground within the floodplain. During the final thousand years or so before the arrival of the Spanish, the area appears to have been rather densely populated with four different societies inhabiting the area, all belonging to the Sonsoide tradition but with variations in pottery style and burial customs. Excavations at the site of La Colonia indicate that the society now known as El Guachal was the most recent to inhabit the area.

\section{Limitations and future plans}

Studies of pollen and phytoliths are planned for the El Nilo core with the object of obtaining valuable information on the local vegetation and environment at a very early period that should, at the latest, correspond to a point during the closing millennia of the Pleistocene. A study of phytoliths is also planned for the Higueroncito site with the aim of documenting changes in vegetation that probably accompanied the sequences of environmental stability and instability detected in the soil studies. It is hoped that there will also be evidence of human activity in the area.

An attempt will be made to find evidence for the dry period, postulated for the southern area for the early part of the Late Holocene, which has not yet been detected in the northern area.

A vital aspect of our project will be the additional analysis of samples from deep cores, not only for fossil pollen and phytoliths but also for their content of microscopic charcoal which might, when taken in conjunction with the palaeobotanical evidence, indicate human impact on the environment during the Early or Mid Holocene periods. It is hoped that these palaeobotanical studies of the paleosols at lesser depths will produce valuable information on the development of horticulture in the region as well as on human activities, or their absence, during what, at present, appears to be a period of archaeological silence.

Now that we know the type of environment favored by the hitherto unknown society that inhabited the wetlands at El Paso, we hope to be able to discover further related sites and expand 
our knowledge of the populations of the early and middle millennium BC. However, the fact that this example is at a depth of nearly seven meters below the current surface, suggests that the search will not be easy.

It is hoped that, as a by-product of our main research, some information will be obtained on the chronological order of the four societies inhabiting the northern research area during the Late Period, together with information on these related cultures.

\section{Acknowledgements}

We gratefully acknowledge funding provided by the Fundación de Investigaciones Arqueológicas Nacionales (FIAN) del Banco de la República and by the Pro Calima Foundation. The cooperation of the palynology laboratory of the Department of Geography, University of Leicester, was invaluable for the preparation and study of the pollen from the Cauca 3 site. In the field we were helped by many people in numerous different ways but we would particularly like to thank Luis Fernando Lopez, director of the Casa de la Cultura in Toro, and, very especially, the late professor Enrique Marmolejo for his unconditional support.

\section{References}

Aceituno, F.J, Rojas-Mora, S., 2015. Lithic technology studies in Colombia during the Late Pleistocene and Early Holocene. Chungara, 47, 13-23.

Álvarez-López, H. 1999. Guía de las Aves de la Reserva Natural Laguna de Sonso. Corporación Autónoma Regional del Valle del Cauca, Cali.

André, É. 1883. Le Tour du Monde: Nouveau Journal des Voyages. Hachette, Paris.

Arroyave, V. , L. Herrera and C.E. López. 2018. Tecnología, forma y función de Instrumentos

Bifaciales Multiuso Enmangables (IBME) del Aeropuerto del Café (Palestina, Caldas, Colombia). Report.

Atlas de Colombia, 1977. Instituto Geográfico Agustín Codazzi, 3rd edition. Litografía Arco, Bogotá.

Behling, H., Hooghiemstra, H. 2000. Holocene Amazon rainforest-savanna dynamics and climatic implications: high-resolution pollen record from Laguna Loma Linda in eastern Colombia. Quaternary. 15, 687-695.

Berrío, J.C., Hooghiemstra, H., Marchant, R., Rangel, J.O. 2002. Late-glacial and Holocene history of the dry forest area in the south Colombian Cauca Valley. Quaternary. 17, 667-682. Bray, W. 2012. Excavations in the Valle del Cauca, 1964, in: Cardale de Schrimpff, M., Groot, A.M., and Botero, P. (Eds), Ocupaciones Humanas y el Medio Ambiente en el valle del río Cauca, 8000-0 A.C. Fundación de Investigaciones Arqueológicas Nacionales, Bogotá. Anexo 1. Unpublished report.

Bray, W., 1989. Cerámica Buga: reevaluación. Boletín del Museo del Oro 24, 102-119. 
Bray, W., Moseley, M.E. 1971. An archaeological sequence from the vicinity of Buga. Nawpa Pacha. 7-8, 85-109

Bray, W., Cardale de Schrimpff, M., Herrera, L., Legast, A., Patiño, D., and Rodríguez, C.A. 2005. Lords of the Marshes. The Malagana people, in: Cardale de Schrimpff, M. (Ed), Calima and Malagana. Art and Archaeology of Southwestern Colombia. Pro Calima Foundation, Bogotá, pp. 140-201.

Cardale de Schrimpff, M., Herrera, L., Bray, W. 2005. The earliest inhabitants, in: Cardale de Schrimpff, M. (Ed.), Calima and Malagana. Art and Archaeology in Southwestern Colombia. Pro Calima Foundation, Bogotá, p. 26-35.

Cardale de Schrimpff, M., Botero, P., Groot, A.M., Betancourt, A., Berrío, J.C. 2009. El Hombre y el Medio Ambiente en el Valle del río Cauca (sector departamento del Valle). 8000-0 A.C. First Phase. Final Report presented to the Fundación de Investigaciones Arqueológicas Nacionales, Bogotá.

Cardale de Schrimpff, M., Botero, P., Groot, A.M., Betancourt, A., Berrío, J.C., Duncan, N., 2012. Ocupaciones humanas y el medio ambiente en el valle del río Cauca (sector Laguna de Sonso) 8.000 - 0 BC, Second Phase. Final Report presented to the Fundación de Investigaciones Arqueológicas Nacionales, Bogotá.

Cardale de Schrimpff, M., Botero, P., Groot, A.M., Berrío, J.C., Duncan, N., 2015. El Formativo y sus Antecedentes en el Sector Septentrional del valle aluvial del río Cauca (8000 a.C. - 500 d. C. Final Report presented to the Fundación de Investigaciones Arqueológicas Nacionales, Bogotá. Cardale de Schrimpff, M., Groot, A.M., Botero, P., Berrío, J.C., Duncan, N. 2015.

Medio ambiente y cultura en el valle aluvial del río Cauca, Colombia: del Precerámico al Formativo. Paper presented to the 55th International Congress of Americanists, symposium Paleoclima, Arqueología e Interacción Humana en América Latina organised by Mario Rivera and Marianne Cardale de Schrimpff, San Salvador, julio 2015.

Cardale de Schrimpff, M., Groot, A.M., Botero, P., Berrío, J.C., Duncan, N. 2016. A difficult environment with extraordinary advantages. Strategies for survival on the flood plain of the river Cauca during the Holocene. Paper presented to the symposium organised by Mariano Bonomo (Universidad Nacional de La Plata/Argentina), Sonia Archila (Universidad de los Andes/ Colombia, and Christine Hasdorf (University of California-Berkeley/USA). WAC 8, World Archaeology Congress, Kyoto.

Cardale de Schrimpff, M., Groot, A.M., Botero, P., Berrío, J.C., Duncan, N. 2017. Lo que el estudio de suelos aporta a la arqueología y lo que la arqueología aporta al estudio de suelos - el caso del valle aluvial del rio Cauca. Paper presented to the V Taller de Geoarqueología de América Latina, Geoarqueología en Tierras Tropicales. 7th - 11th November 2017, Manizales, Caldas, Colombia.

Cardale de Schrimpff, M., Botero, P., Bray, W., Groot, A.M., Berrío, J.C., Duncan, N. 2018. El "Paleosuelo Yotoco". Paper presented at the II Jornadas de Arqueología en Colombia, Museo Universitario, Departamento de Antropología, Universidad de Antioquia, Medellín, 6th- 9th March, 2018.

Cieza de León, P. [1553] 1962. La Crónica del Perú. Madrid. Editorial Espasa - Calpé, Madrid. Correal, G., van der Hammen, T., 2003. Supervivencia de Mastodontes, Megaterios y presencia del hombre en el valle del Magdalena (Colombia) entre 6000 y 5000 AP. Revista de la Academia Colombiana de Ciencias Exactas, Físicas y Naturales. 27, 159-164. 
Cluny, C., Mazier, F., Galop, D., 2010. Modern and fossil non-pollen palynomorphs from the Basque mountains (western Pyrenees, France): the use of coprophilous fungi to reconstruct pastoral activity. Vegetation History and Archaeobotany. 19, 391-408.

Chepstow-Lusty, A., Bennett, K.D., Fjeldsa, J., Kendall, A., Galiano, W., Herrera, A.T., 1998. Tracing 4000 years of environmental history in the Cuzco area, Peru, from the pollen record. Mountain Research and Development. 18, 59-172.

Díaz Merlano, J. M., 2006. Bosque seco tropical, Colombia. Banco de Occidente, Cali. Dickau, R., Aceituno, F.J., Loaiza, N., López, C., Cano, M., Herrera, L., Restrepo, C., Ranere, A.J., 2015. Radiocarbon chronology of terminal Pleistocene to middle Holocene human occupation in the Middle Cauca Valley, Colombia. Quaternary International. 363, 43-54. Duncan, N., Cardale de Schrimpff, M., Groot, A.M., Botero, P., Betancourt, A., Berrío, J.C., 2013. Human Occupation and the Environment during the Holocene in the River Cauca Valley, Colombia: the evidence from palaeobotany and from soil studies. Diálogo Andino. 41, 159-170.

Faegri, K. Iversen, J., 1989. Text book of pollen analysis, $\left(4^{\text {th }}\right.$ ed.). Willey, Chichester.

Ford, J. A., 1944. Excavations in the vicinity of Cali, Colombia. Yale University Publications in Anthropology 31, New Haven.

Grimm, E.C., 1990. TILIA and TILIA.GRAPH. PC spreadsheet and graphics software for pollen data. INQUA working group on data-handling methods, Newsletter. 4: 5-7.

Herrera, L., Cardale de Schrimpff, M., Bray, W., Botero, P., 1992. Nuevas fechas de radiocarbono para el Precerámico en la cordillera Occidental de Colombia, in Ortiz-Troncoso, O. and van der Hammen, T. (Eds), Archaeology and Environment in Latin America. Universiteit van Amsterdam, Amsterdam, pp. 145-163

Herrera, L.F., Urrego, L.E., 1996. Atlas de polen de plantas útiles y cultivadas de la Amazonía Colombiana. Estudios en la Amazonía Colombiana 11.Tropenbos Colombia, Bogotá.

Herrera, L., Cardale de Schrimpff, M., Archila, S., 2007. Coronado, un cementerio de la Cultura Malagana, excavaciones iniciales. Banco de la República, Bogotá.

Herrera, L., Moreno, M.C., Peña, O., 2011. La historia muy antigua del municipio de Palestina (Caldas). Centro de Museos-Universidad de Caldas, Asociación Aeropuerto del Café, Manizales. Hooghiemstra, H., 1984. Vegetational and climatic history of the high plain of Bogotá, Colombia: a continuous record of the last 3.5 million years. Dissertationes Botanicae. 79, 368.

Instituto Geográfico Agustín Codazzi, 2004. Levantamiento de suelos y zonificación de tierras del Departamento de Valle de Cauca. Vol. 1.

Kiage, L.M., Liu, K.B., 2009. Palynological evidence of climate change and land degradation in the Lake Baringo area, Kenya, East Africa, since AD 1650. Palaeogeography, Palaeoclimatology, Palaeoecology. 279, 60-72.

Kuentz, L., Ledru, M.P., Thouret, J.C., 2012. Environmental changes in the highlands of the western Andean Cordillera, southern Peru, during the Holocene. The Holocene. 22, 1215-1226. Monsalve, M.L., Toro-Villegas, M.E., 2016. Informe visita a sector arqueológico en el municipio de Toro, norte del departamento del Valle. Servicio Geológico Colombiano, Bogotá

Moreno, M.C., Briceño, P.P., Quintana, L., 1999. Arqueología de rescate. Línea de transmisión eléctrica a 500 KV San Carlos-San Marcos. Universidad de Caldas, Manizales.

Patiño, D., Xiomara López, Martha Hernández and Carlos Acosta. 2004. Excavaciones arqueológicas en la malla vial del Valle del Cauca y Cauca (Fase II). Universidad del Cauca, Fundación General de Apoyo - Unión Temporal Desarrollo Vial del Valle del Cauca y Cauca. Final Report. 
Pérez de Barradas, José. 1966.Orfebrería Prehispánica de Colombia. Estilos Quimbaya y otros. 2 tomos. Banco de la República, Museo del Oro, Bogotá. Madrid.

Piperno, D., Pearsall, D., 1998. The Origins of Agriculture in the lowland Neotropics. Academic Press, San Diego- Nueva York- London.

Reichel-Dolmatoff, G., 1986. Arqueología de Colombia. Un texto introductorio. Litografia Arco, Bogotá.

Revelles, J., van Geel, B. 2016. Human impact and ecological changes in lakeshore environments. The contribution of non-pollen palynomorphs in Lake Banyoles (NE Iberia). Review of Palaeobotany and Palynology. 232, 81-97.

Rodríguez Flórez, Carlos David, Ernesto Leon Rodríguez Flórez y Carlos Armando Rodríguez, 2009. Revisión de la Fauna Pleistocénica Gomphotheriidae en Colombia y reporte de un caso para el Valle del Cauca. Boletín Científico 13, (2); 78-85. Centro de Museos, Museo de Historia Natural, Universidad de Caldas, Manizales.

Rodriguez, C.A., 1989. La población prehispánica del valle medio del rìo Cauca entre los siglos VII-XVI D.C. (Culturas Guabas y Buga). Boletín del Museo del Oro, 24, 73-89.

Rodríguez, C.A., 1998. San Luis: un asentamiento temprano de la Cultura Sonso en la llanura aluvial del Pacífico. Boletín de Arqueología, Fundación de Investigaciones Arqueológicas Nacionales, Banco de la Republica, 3 (2): 41-55. Bogotá.

Rodríguez, C.A., 2002. El Valle del Cauca Prehispánico. Fundación Taraxacum, Washington D.C. Rodríguez, J.V., Rodríguez, C.A., 1998. Patrones de enterramiento Quimbaya Tardío en el sitio arqueológico Dardanelos, municipio de Obando, departamento del Valle de Cauca. Boletín de Arqueología, Fundación de Investigaciones Arqueológicas Nacionales, Banco de la Republica. 13, (2), 81-111.

Rodríguez, J.V., Blanco, S., Botero, P., 2005. Comunidad prehispánica de El Cerrito, Valle del Cauca. Medio ambiente, prácticas funerarias y condiciones de vida. Universidad Nacional de Colombia, Bogotá.

Rodríguez, J.V., Blanco, S., Clavijo, A., 2007. Rituales funerarios y chamanismo en el cementerio de Coronado (Siglos III a.C. a III d.C.), en J.V. Rodríguez, (Ed.), Territorio ancestral, rituales funerarios y chamanismo en Palmira prehispánica, Valle del Cauca. Universidad Nacional de Colombia, Bogotá, p. 81-138.

Rodríguez-Flórez, C.D., Rodríguez-Flórez, E. L., Rodríguez, C.A., 2009. Revisión de la Fauna Pleistocénica Gomphotheriidae en Colombia y reporte de un caso para el Valle del Cauca. Boletín Científico. 13, 78-85.

Roubik, D.W., Moreno, J.E., 1991. Pollen and Spores of Barro Colorado Island. Botanical Garden 36, Missouri.

Rull, V., Abbott, M.B., Polissar, P.J., Wolfe, A.P., Bezada, M., Bradley, R.S., 2005. 15,000-yr pollen record of vegetation change in the high altitude tropical Andes at Laguna Verde Alta, Venezuela. Quaternary Research. 64, 308-317.

Salgado, H. and Stemper, D., 1995. Cambios en Alfarería y Agricultura en el centro del Litoral Pacífico Colombiano durante los dos últimos milenios. Fundación de Investigaciones Arqueológicas Nacionales, Banco de la Republica, Bogotá.

Sauer C.O., 1952. Agricultural Origins and Dispersals. American Geographical Society, New York. Siegel, P.E., Jones, G. J., Pearsall, D.M., Dunning, N.P., Farrell, P., Duncan, N.A., Curtis, J.H., Singh, S.K. Paleoenvironmental evidence for first human colonization of the eastern Caribbean. Quaternary Science Reviews. 129, 275-295. 
Velez, M.I., Martínez, J.I., Suter, F., 2013. Late Holocene history of the floodplain lakes of the Cauca River, Colombia. Journal of Paleolimnology. 49, 591-60. 


\section{CAPTIONS}

\section{FIGURES}

Figure 1. Aerial view of the river Cauca floodplain near Toro, with the location of some of the principal sites mentioned in the text. October 2015. Photograph: Foto Rudolf.

Figure 2. Map showing part of the Western Cordillera and the floodplain of the river Cauca valley with the areas investigated. Instituto Geográfico Agustín Codazzi, 1980.

Figure 3. A reconstruction of the cultural chronology for the northern part of the river Cauca floodplain.

Figure 4. The stratigraphy from the lower section of the core at El Nilo.

Figure 5. Map showing part of the research area with the principal sites mentioned.

Figure 6. Detail of a rib from the mastodon found in Toro with cut marks from butchering. Casa de la Cultura, Toro. Photograph courtesy of Carlos López, Martha Cano and Tony Ranere.

Figure 7. Lithology and pollen information from Cauca 3.

Figure 8. 1. Paleosols revealed in the bank of the river Cauca during an exceptionally dry season. 2. Cauca 3. Bank exposure complemented by drilling with an auger permitted the study of a soil profile over $15 \mathrm{~m}$ deep. 3. A stretch of the river Cauca photographed from Cauca 3.

Figure 9. A stone hoe of a type characteristic of the Early Holocene in southwestern Colombia. Length 13 x $10 \mathrm{~cm}$. San José de los Osos, Toro.

Figure 10. Analysis of fossil pollen from Cauca 3.

Figure 11. Stratigraphy from the stream bank at the Quebrada Higueroncito.

Figure 12. Higueroncito. The excavation on the terrace a few meters from the stream. The different horizons appear to be the result of periods of environmental stability and instability.

Figure 13. The El Paso site: A. exposed due to the abnormally low water level in the river Cauca. B. The river bank with incipient palaeosols above the El Paso horizon. C. Profile of the river bank revealing palaeosols and ancient dykes that formed above the El Paso horizon. D. The dark cultural horizon buried beneath marsh sediment.

Figure 14. Some finds from the El Paso site.

Figure 15. A tentative reconstruction of the El Paso site and its formation.

Figure 16. Items from three different Late Period pottery styles of the Sonsoide tradition found in the Toro Area. A: a figurine of the "retablo" style, relatively common in the Toro area, private collection; photograph, Karen Bruhns; B: Buga-Guabas style, h. 22 cm, Casa de la Cultura, Toro. C:

Anthropomorphic vessel characteristic of the El Guachal style, a late group within the Sonsoide tradition. H. $35 \mathrm{~cm}$, Casa de la Cultura, Toro. 


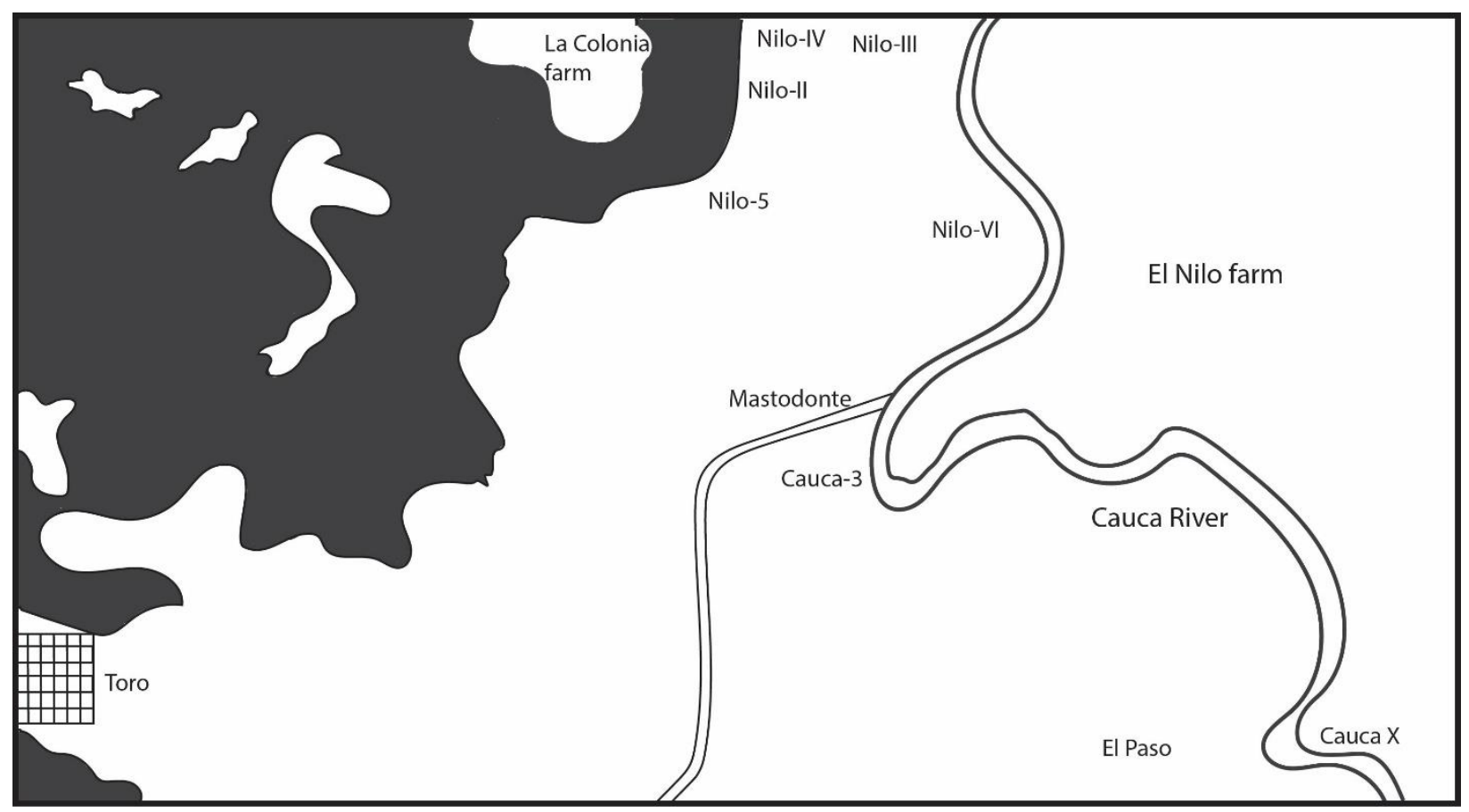

Fig. 1

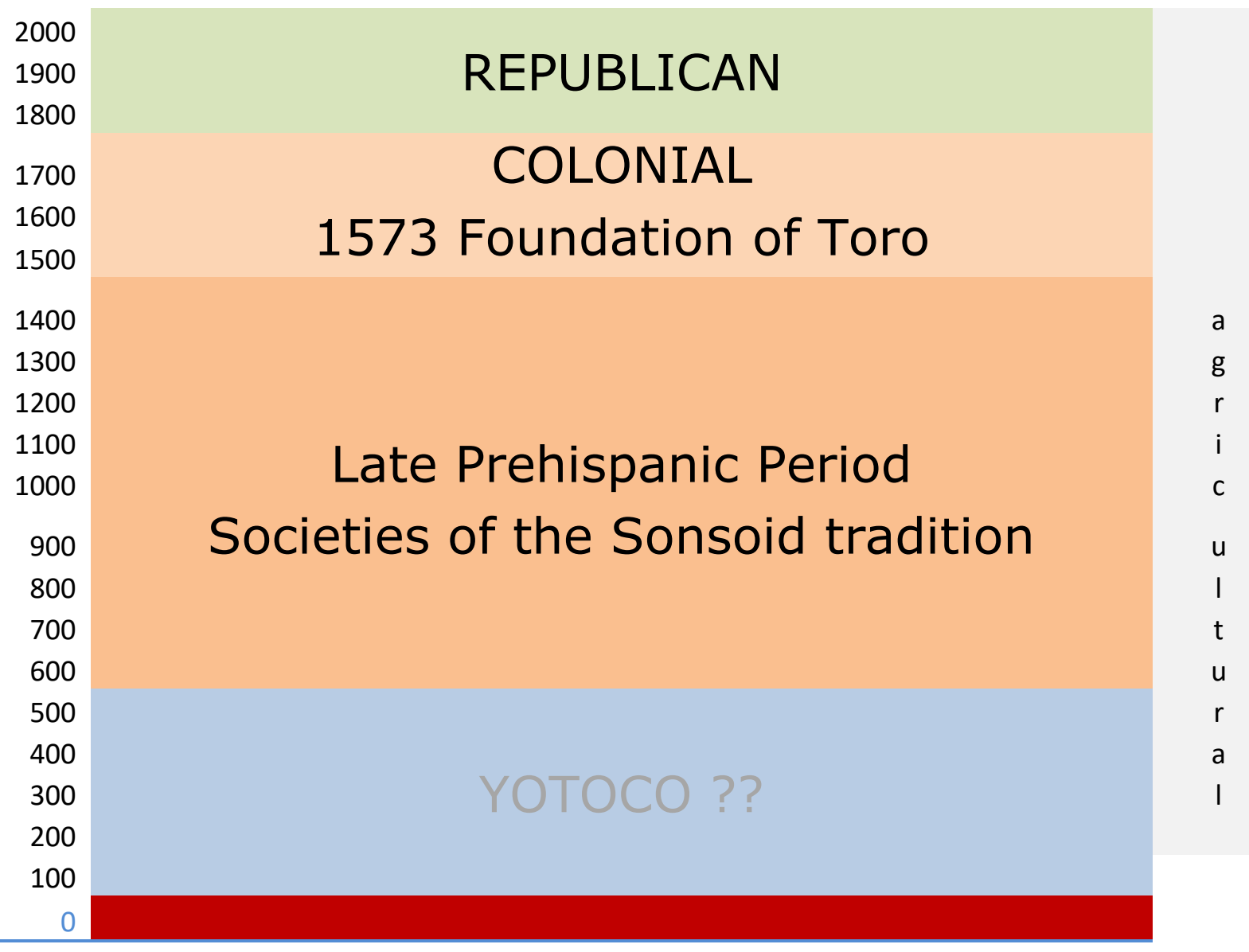




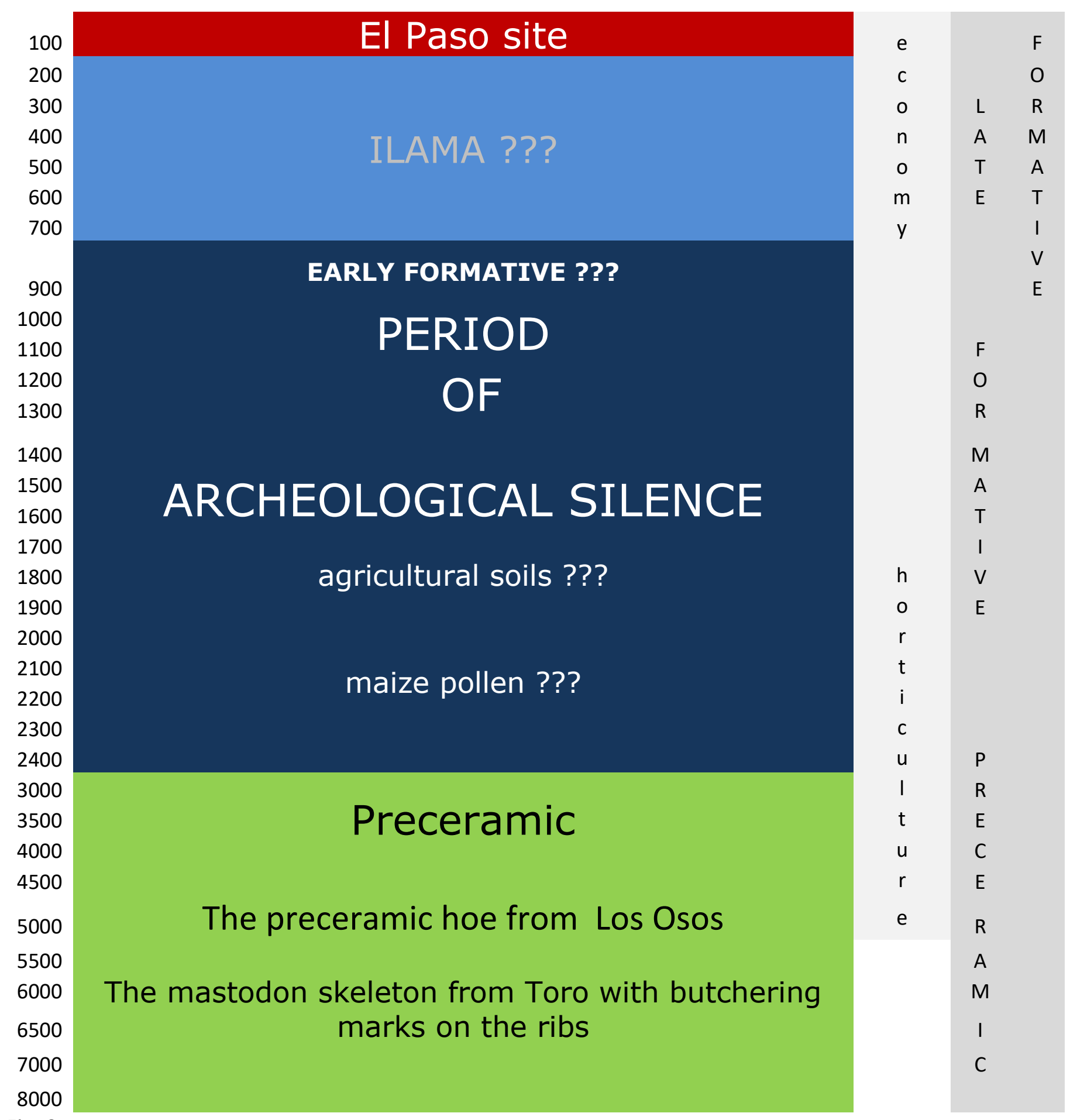

Fig. 2 


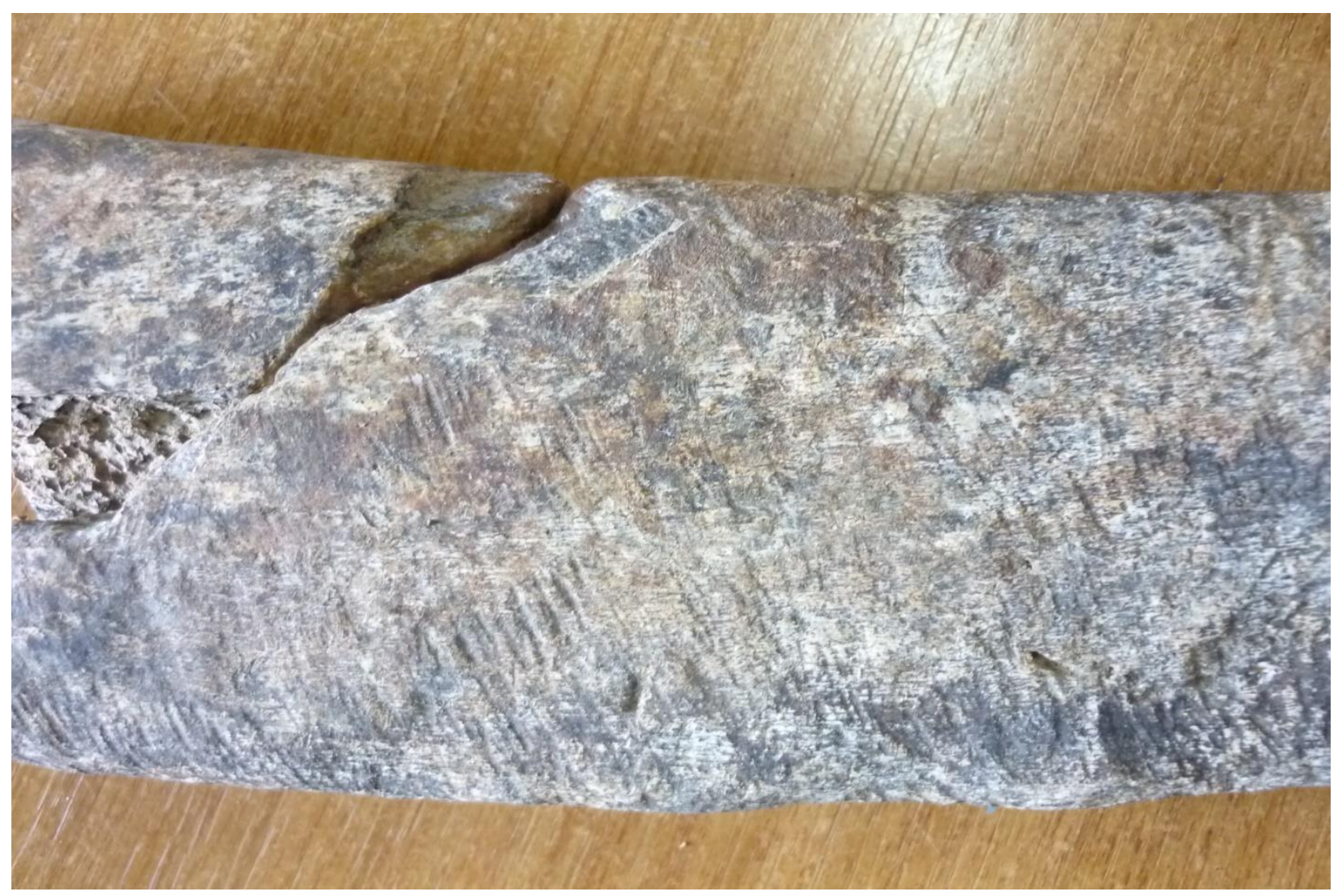

Fig. 4 


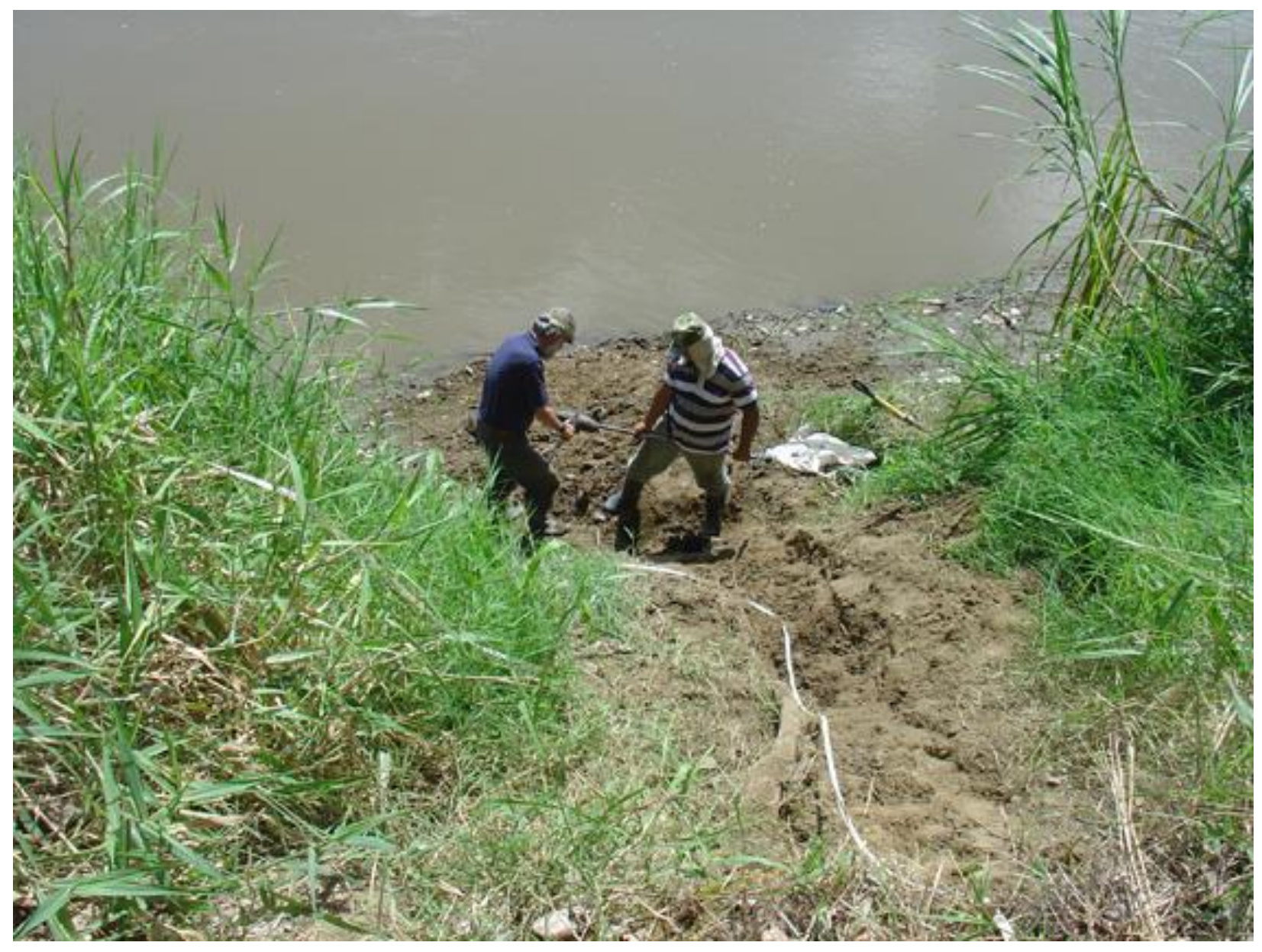

Fig 5.

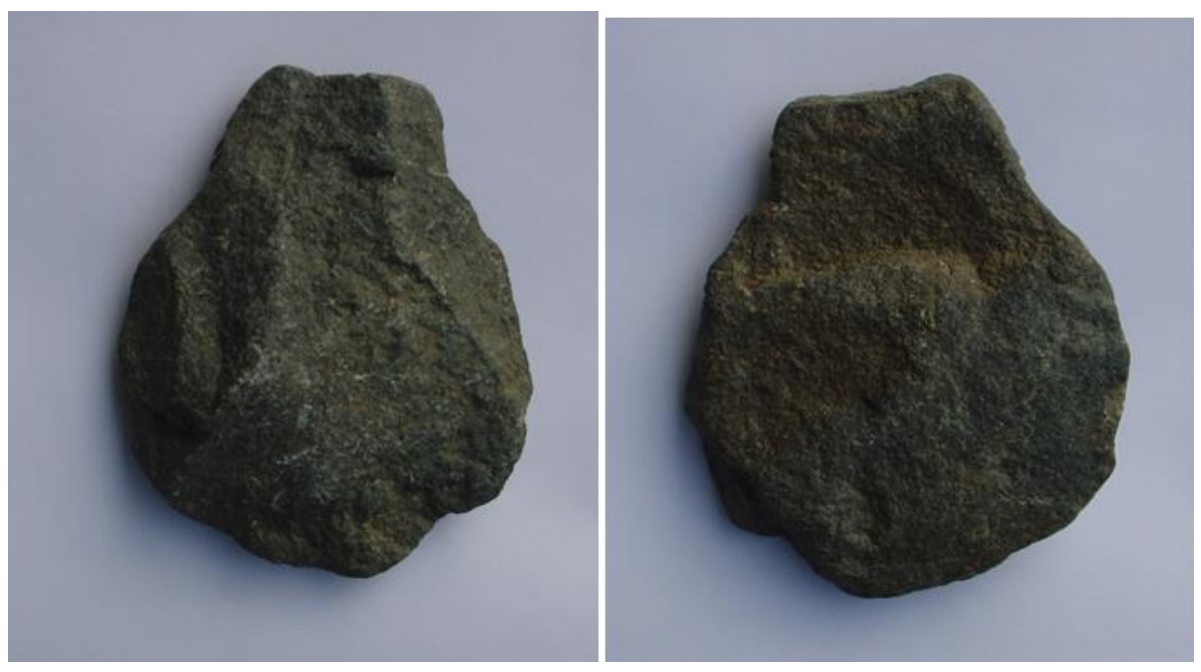

Fig. 6 


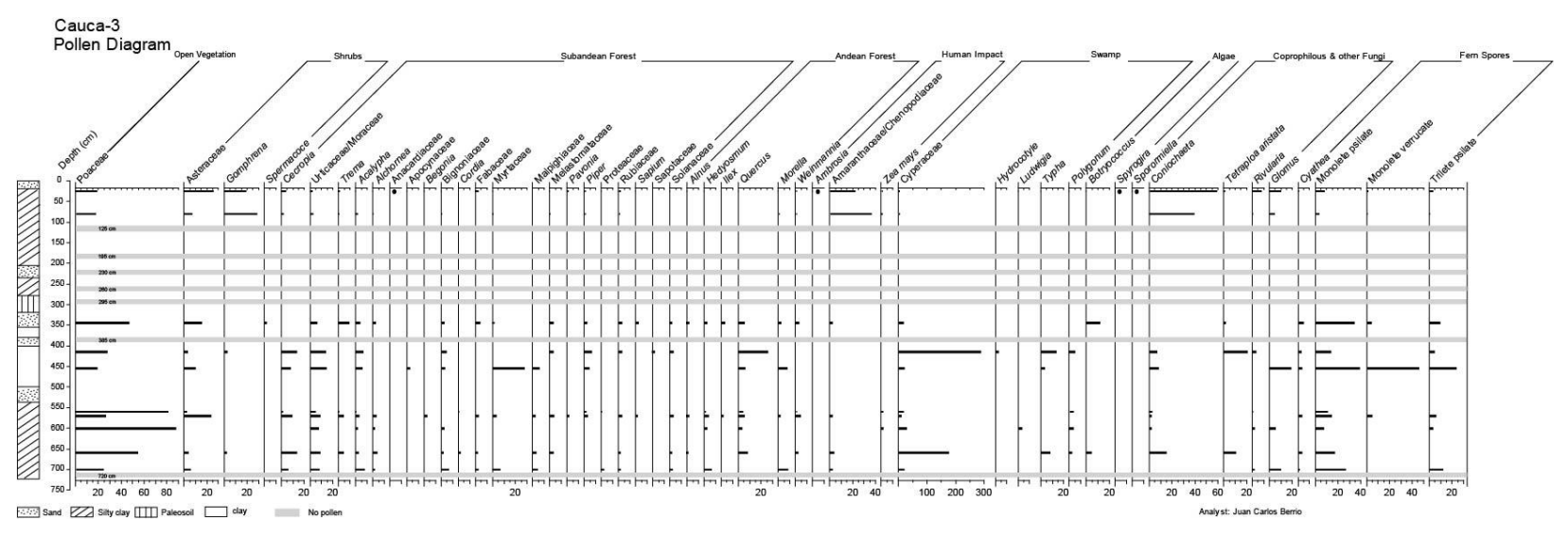

Fig. 7 


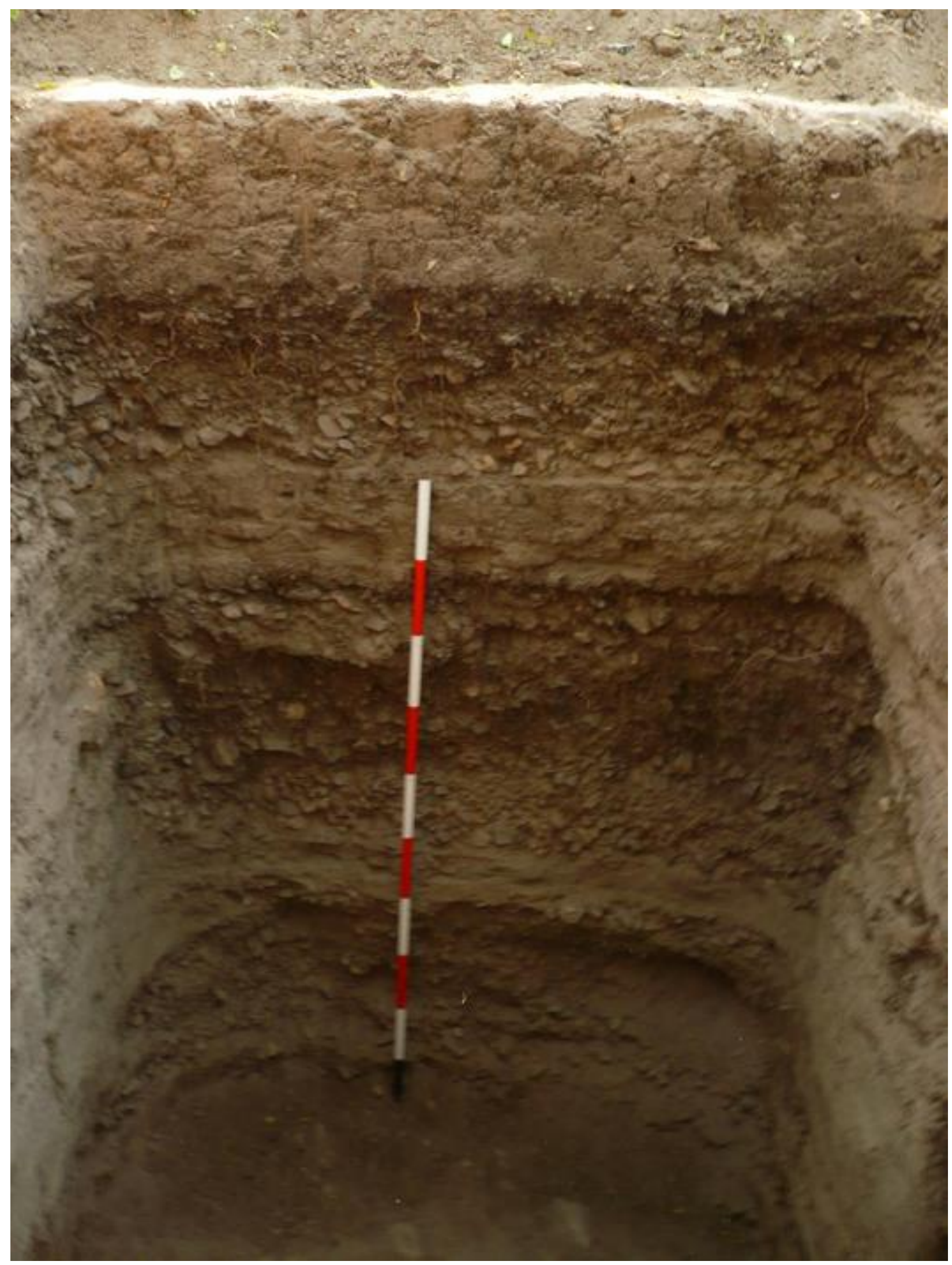

Fig. 8 

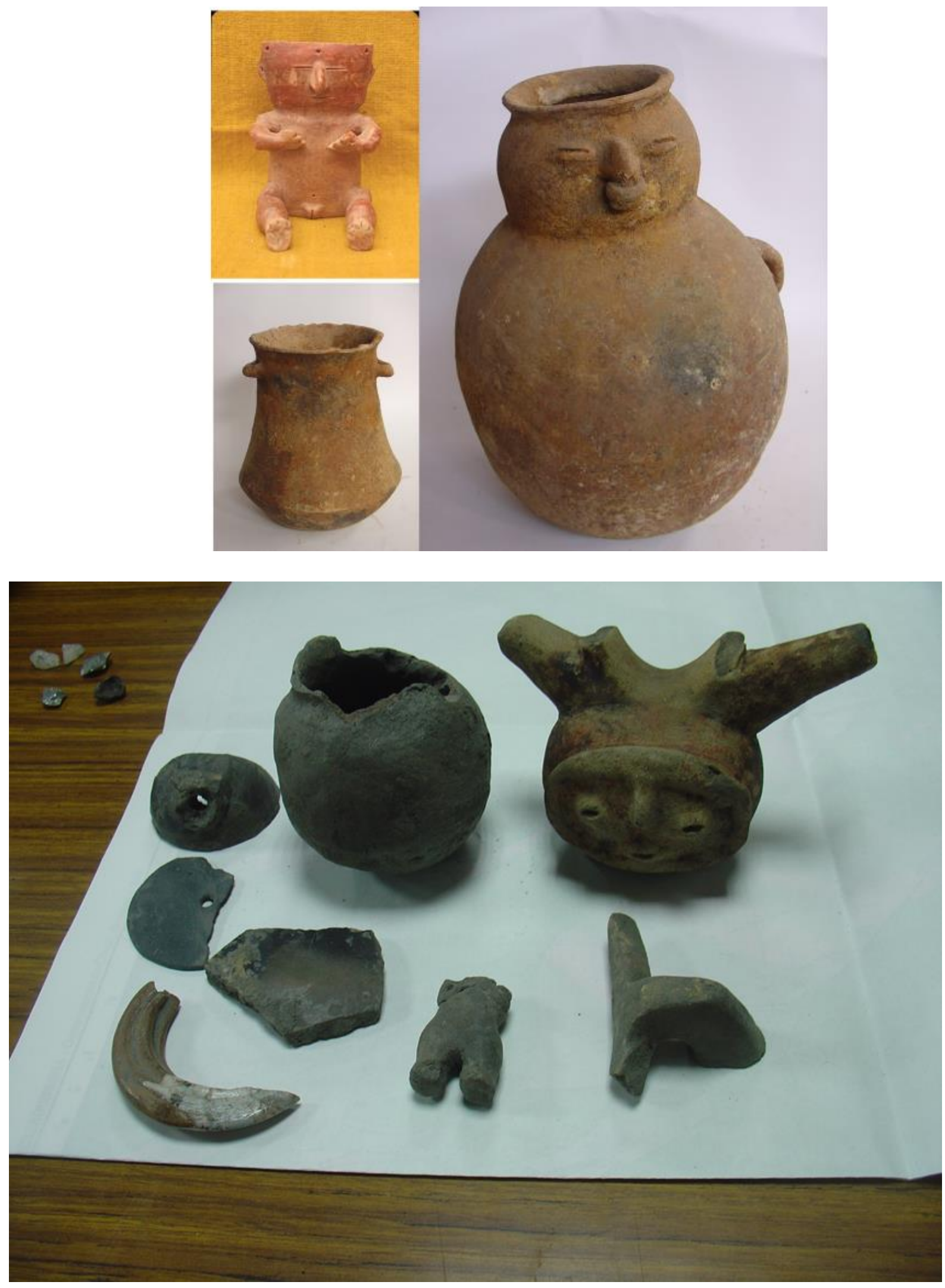

Fig.

Fig. 10 


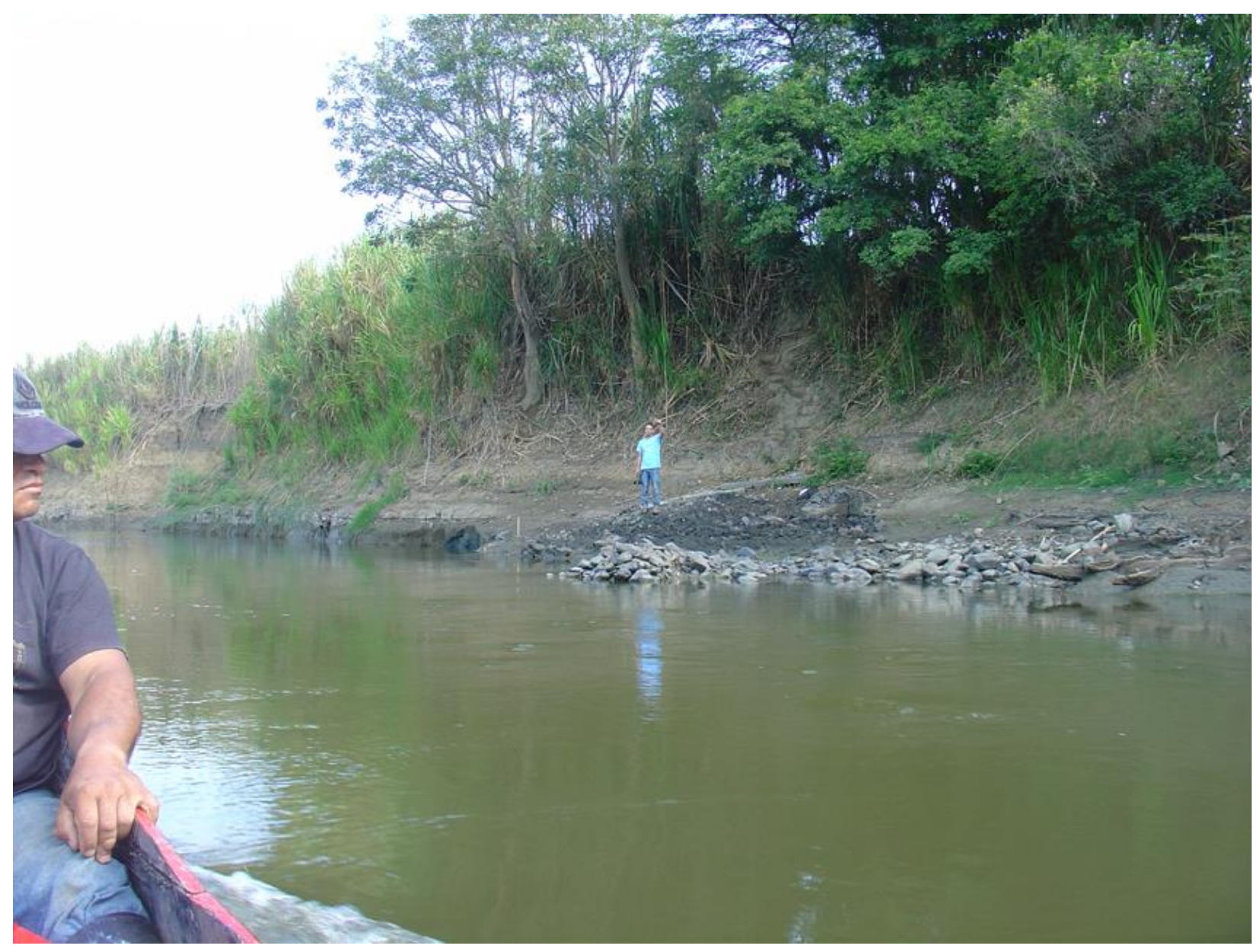

Fig. 11 


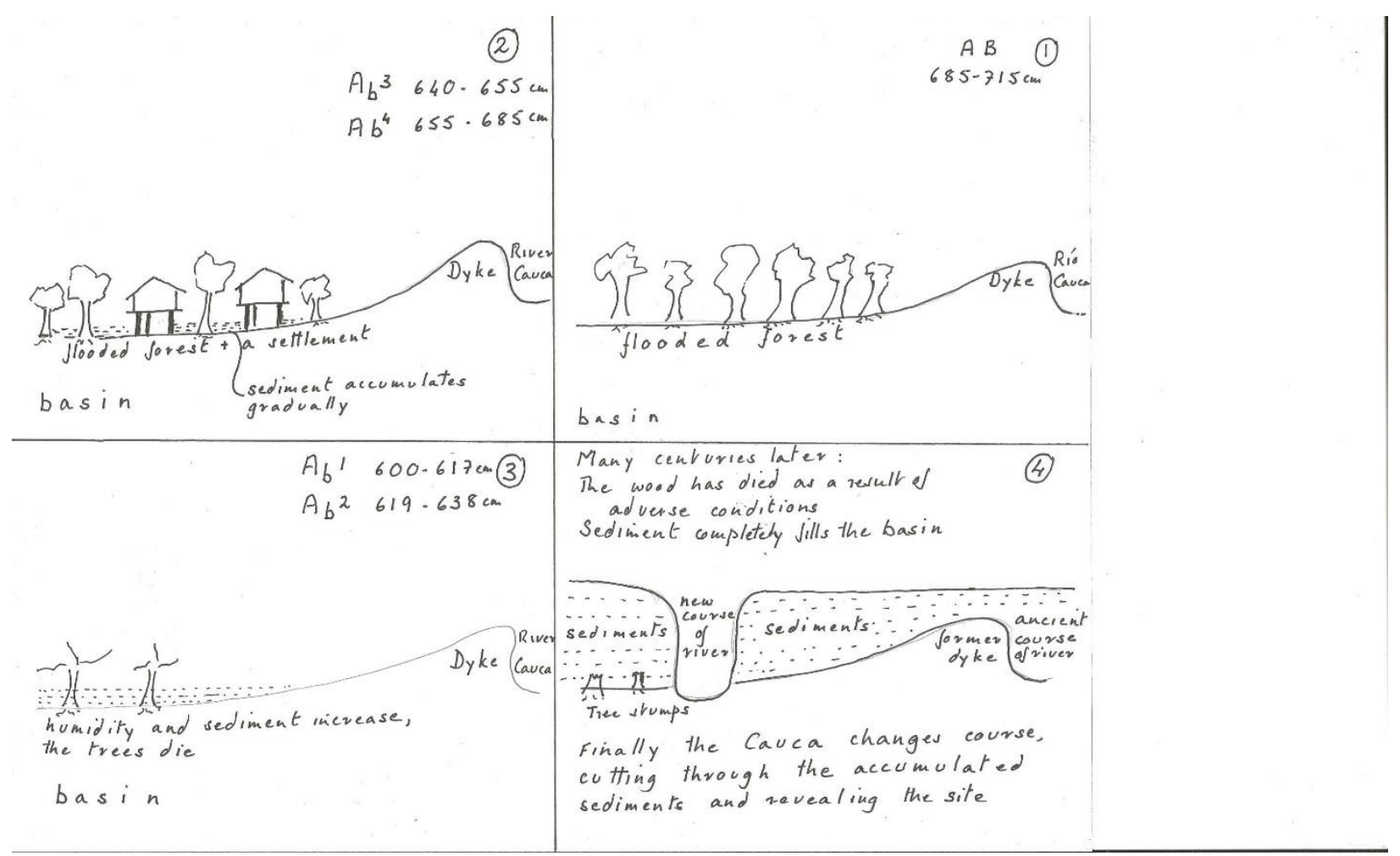

Fig. 12

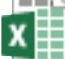

Table 1.

Radiocarbon dates.) 